\title{
Eschenmoser coupling reaction of selenoamides. Synthesis of enamino ester
}

\author{
Syed R. Hussaini and Gerald B. Hammond* \\ Department of Chemistry, University of Louisville, Louisville, KY 40292, USA. \\ E-mail: gb.hammond@,louisville.edu
}

\begin{abstract}
The first report of the Eschenmoser coupling reaction of selenoamides is reported here. The reaction provides access to cyclic enaminoesters under mild conditions for selected cases.
\end{abstract}

Keywords: Eschenmoser coupling reaction (sulfide contraction), selenoamides, enaminoesters, vinylogous urethanes, vinylogous amides, Woollins reagent

\section{Introduction}

The versatility of enamino esters or urethanes and vinylogous amides is evident by their successful utilization in the synthesis of many natural products. ${ }^{1-3}$ These compounds can also provide rapid access to substituted pyrrolidines. ${ }^{4-6}$ Substituted pyrrolidines fall under the important and rapidly growing category of proline-based organocatalysts. For enantioselective transformations, proline and proline-based organocatalysts have been utilized in many different reactions, including the aldol, Mannich, halogenation, conjugate addition, alkylation, cycloaddition, cyclopropanation and epoxidation reactions. ${ }^{7,8}$ Thus, the synthesis of enamino esters is an important area in organic synthesis.

The Eschenmoser coupling reaction (sulfide contraction) is an efficient method to prepare vinylogous amides and urethanes. The reaction requires mild conditions and is tolerant of various functional groups and the preservation of base sensitive stereocenters is possible. The reaction mechanism consists of two distinct steps: (i) reversible $S$-alkylation of thioamides with electrophiles to form $\alpha$-thioiminium salts or $\alpha$-thioimine and, (ii) deprotonation of the $\alpha$-proton by a base, followed by sulfur extrusion to give the alkenic bond. The second step is believed to go through the formation of an episulfide intermediate. ${ }^{1}$

There are some limitations to the reaction. One notable limitation has to do with the reversibility of the first step of the mechanism, which does not allow the reaction to proceed forward in certain cases. The other notable limitation is the failure of the sulfide-contraction of 
many secondary thiolactams. The first limitation has been circumvented, for specific cases, by the use of non-nucleophilic leaving groups on the electrophiles. The second limitation has been overcome, for particular cases, by the use of tertiary thiolactams and thiophiles ${ }^{1,2,9}$ or by the use of Knoevenagel-based modification. ${ }^{6,10}$ Still, the solutions are not general or require multiple steps for the transformation. This can be seen by the failure of the attempted coupling of bromo monoesters or bromoacetonitrile with thioxopyrrolidines $\mathbf{1}$ and $\mathbf{2}$ under various mildly basic conditions (Scheme 1).

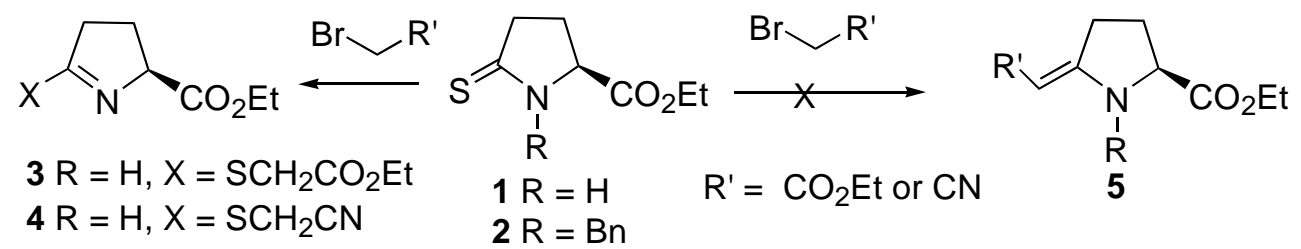

\section{Scheme 1}

In this reaction, iminothioether 3 was obtained when thiolactam 1 was treated with ethyl bromoacetate, using either Rapoport's conditions [i) $\mathrm{BrCH}_{2} \mathrm{CO}_{2} \mathrm{Et}, \mathrm{CH}_{3} \mathrm{CN}, \mathrm{RT}, 40 \mathrm{~h}$, ii) $\mathrm{PPh}_{3}$, $\mathrm{Et}_{3} \mathrm{~N}$, RT, $\left.20 \mathrm{~h}\right]^{11}$ or Bachi's conditions $\left(\mathrm{NaHCO}_{3}, \mathrm{CH}_{2} \mathrm{Cl}_{2}\right.$, reflux, $\left.36 \mathrm{~h}\right)$, ${ }^{12}$ or microwave irradiation (Scheme 1). Reaction with bromoacetonitrile $\left(\mathrm{NaHCO}_{3}, \mathrm{CH}_{2} \mathrm{Cl}_{2}, \mathrm{MW}\right)$ gave product 4, which is also the result of $S$-alkylation. Strong bases, such as $\mathrm{KO} t$-Bu have previously been used for sulfide-contraction. ${ }^{13}$ However, only mild basic conditions were screened as strong bases could racemize the $\mathrm{C}-2$ position of such thiolactams. The $N$-benzylated thiolactam 2 , under Rapoport's conditions ${ }^{3}$ did not give the desired enamine 5. Instead the hydrolyzed product amide was obtained. ${ }^{14}$ Such cases have been reported previously. ${ }^{11,15}$ To overcome these problems, the use of selenoamides instead of thioamides, was contemplated. As selenium is more nucleophilic than sulfur, we expected the $S e$-alkylation to be more facile and it was thought that this would solve the problem with the reversibility of the first step. Also, it is probable that the conversion of deprotonated $\alpha$-thioiminium salts or $\alpha$-thioimine to episulfide is reversible. If so, we expected that the presence of selenium instead of sulfur might expedite the process of selenium extrusion, thus shifting the equilibrium towards the alkenic bond. It has been reported that selenium extrusion from episelenide is easier than sulfur extrusion from episulfide. ${ }^{16}$ Furthermore, as the difference in the electronegativity of sulfur and selenium is very small we expected the deprotonation of $\alpha$-selenoiminium salts or $\alpha$-selenoimine to be as easy as that of their sulfur analogues.

Selenoamides are well known in organic chemistry. However, their synthesis was a challenge until the discovery of a mild selenating agent, namely, Woollins reagent ${ }^{17 \mathrm{a}}\left(\mathrm{Ph}_{2} \mathrm{P}_{2} \mathrm{Se}_{4}\right)$. Highly efficient synthesis of $N, N$-disubstituted selenoamides have been reported using this reagent. ${ }^{17 \mathrm{~b}}$ Recently, Woollins reagent has been made commercially available. Thus, we expected to get the selenoamides conveniently. We also expected that the use of selenoamides in the Eschenmoser reaction would provide enamino esters under milder conditions, thus broadening the scope of this 
already well-established reaction. ${ }^{1}$ The Eschenmoser reaction, to the best of our knowledge, has not been studied for other group VI elements. Herein we describe the first Eschenmoser coupling reaction of chiral and achiral selenoamides.

\section{Results and Discussion}

Due to reported problems associated with the cyclic version of the Eschenmoser coupling, ${ }^{18}$ we first attempted the reaction on acyclic selenoamides. Selenoamide 7a, using benzene as the solvent, has been synthesized in excellent yield. ${ }^{17 \mathrm{~b}}$ However, in our hands the best yields for selenoamides were obtained when $\mathrm{CH}_{2} \mathrm{Cl}_{2}$ was used as the solvent (eq 1). It is possible that our moderate yield of selenoamide was due to the commercial nature of Woollins reagent. No further attempts were made to improve the yields of selenoamides, instead we decided to investigate if the Eschenmoser coupling would work.
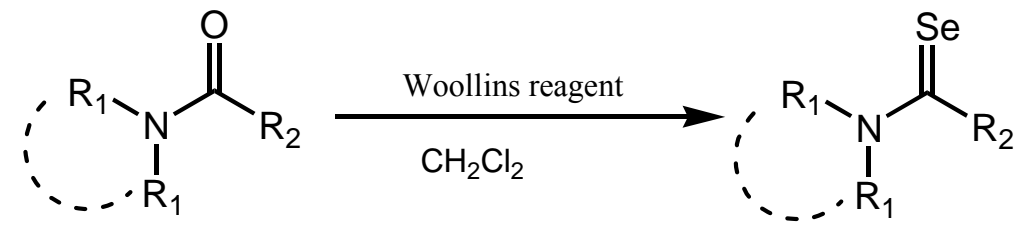

$$
\begin{gathered}
\text { 6a } \mathrm{R}_{1}=\mathrm{CH}_{3}, \mathrm{R}_{2}=\mathrm{H} \\
\text { 6b R } \mathrm{R}_{1}---\mathrm{R}_{1}=\mathrm{CH}_{2}-\left(\mathrm{CH}_{2}\right)_{3}-\mathrm{CH}_{2}, \\
\mathrm{R}_{2}=\mathrm{CH}_{2}(\mathrm{CH})_{5} \mathrm{CH}_{3}
\end{gathered}
$$$$
\text { 7a } 46 \%
$$

The reaction was carried out with dicarbonyl compounds as they are more reactive than monocarbonyl compounds. However, the reaction of 7a with diethyl bromomalonate did not give the desired enamide, instead diethyl malonate was obtained. The reaction of selenoamide 7a with ethyl 2-bromo-3-oxo-3-phenylpropionate also showed only trace amounts of the corresponding enamino ester. These results suggest the occurrence of an Eschenmoser coupling reaction followed by the hydrolysis of enamide. ${ }^{18}$ We next planned to carry out the reaction of the selenium analogue of 1-piperidino-1-octanone. However, 1-piperidino-1-octanone $\mathbf{6} \mathbf{b}^{19}$ failed to provide the selenoamide in workable amounts (eq 1). It seems that the sensitive selenoamide hydrolyses back to the amide upon exposure to air and/or on silica gel. Due to the difficulties with acyclic selenoamides we diverted our efforts to cyclic amides.

The cyclic selenoamides $\mathbf{8}^{17} \mathbf{- 1 0}$ were made to react with mono and dicarbonyl compounds under various conditions (Table 1). Previously reported conditions ${ }^{1}$ for the synthesis of enamino monoesters from thiolactams failed to provide the desired products (entries 1-2 and 7-9). For both chiral and achiral enamino diesters the best yields were obtained when $\mathrm{NaHCO}_{3}$ was used as a base (entries 3-4 and 13). With amine bases, mostly hydrolysed products were observed (entries 1,6 and 10). These results were consistent with previously reported observations. ${ }^{11,18}$ 
Table 1. Eschenmoser coupling reaction of selenoamides with $\alpha$-bromoesters
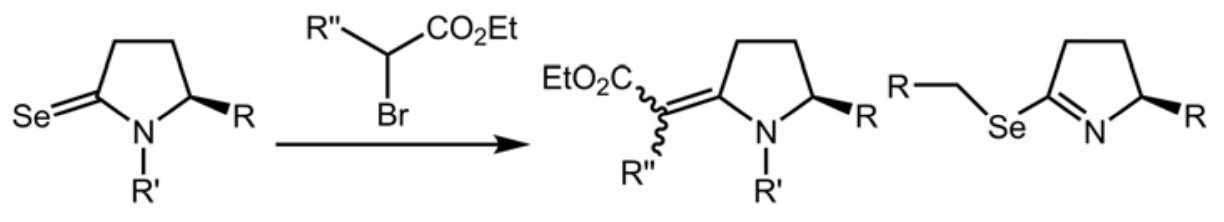
$8 \mathrm{R}=\mathrm{H}, \mathrm{R}^{\prime}=\mathrm{Me}$
$11 \mathrm{R}=\mathrm{H}, \mathrm{R}^{\prime}=\mathrm{Me}, \mathrm{R}^{\prime \prime}=\mathrm{CO}_{2} \mathrm{Et}$
$13 \mathrm{R}=\mathrm{CO}_{2} \mathrm{Et}$
$9 \mathrm{R}=\mathrm{CO}_{2} \mathrm{Et}, \mathrm{R}^{\prime}=\mathrm{Bn}$
$12 \mathrm{R}=\mathrm{H}, \mathrm{R}^{\prime}=\mathrm{Me}, \mathrm{R}^{\prime \prime}=\mathrm{COPh}$
$10 \mathrm{R}=\mathrm{CO}_{2} \mathrm{Et}, \mathrm{R}^{\prime}=\mathrm{H}$
$14 \mathrm{R}=\mathrm{CO}_{2} \mathrm{Et}, \mathrm{R}^{\prime}=\mathrm{H}, \mathrm{R}{ }^{\prime}=\mathrm{CO}_{2} \mathrm{Et}$

\begin{tabular}{|c|c|c|c|}
\hline Entry & Starting materials & Conditions & Products \\
\hline 1 & $\mathbf{8}, \mathrm{R}^{\prime \prime}=\mathrm{H}$ & NMP, $\mathrm{PPh}_{3}, \mathrm{CH}_{2} \mathrm{Cl}_{2}$ & 2-pyrrolidone \\
\hline 2 & $8, R^{\prime \prime}=H$ & $\mathrm{NaHCO}_{3}, \mathrm{CH}_{2} \mathrm{Cl}_{2}, \mathrm{rt}$, \& sonication & - \\
\hline 3 & $\mathbf{8}, \mathrm{R}^{\prime \prime}=\mathrm{CO}_{2} \mathrm{Et}$ & $\mathrm{NaHCO}_{3}, \mathrm{CH}_{2} \mathrm{Cl}_{2}, \mathrm{rt}$ & $11^{20}$ \\
\hline 4 & $\mathbf{8}, \mathrm{R}^{\prime \prime}=\mathrm{COPh}$ & $\mathrm{NaHCO}_{3}, \mathrm{CH}_{2} \mathrm{Cl}_{2}, \mathrm{rt}$ & $26 \%$ \\
\hline 5 & $\mathbf{9}, \mathrm{R}^{\prime \prime}=\mathrm{CO}_{2} \mathrm{Et}$ & $\mathrm{NaHCO}_{3}, \mathrm{CH}_{2} \mathrm{Cl}_{2}, \mathrm{rt}$ & - \\
\hline 6 & $\mathbf{9}, \mathrm{R}^{\prime \prime}=\mathrm{COPh}$ & $\mathrm{NaHCO}_{3}, \mathrm{CH}_{2} \mathrm{Cl}_{2}, \mathrm{rt}$ & benzamide \\
\hline 7 & $\mathbf{1 0}, \mathrm{R}^{\prime \prime}=\mathrm{H}$ & $\mathrm{NaHCO}_{3}, \mathrm{CH}_{2} \mathrm{Cl}_{2}$, reflux & - \\
\hline 8 & 10, R' = H & $\mathrm{NaHCO}_{3}, \mathrm{CH}_{2} \mathrm{Cl}_{2}, \mathrm{MW}$ & - \\
\hline 9 & 10, R" $=\mathrm{H}$ & $\mathrm{NaOEt}, \mathrm{CH}_{2} \mathrm{Cl}_{2}$ & $13 \alpha$-selenoimine \\
\hline 10 & 10, $\mathrm{R}^{\prime \prime}=\mathrm{CO}_{2} \mathrm{Et}$ & $\mathrm{Et}_{3} \mathrm{~N}, \mathrm{PPh}_{3}, \mathrm{CH}_{2} \mathrm{Cl}_{2}$ & $\begin{array}{l}\mathrm{CH}_{2}\left(\mathrm{CO}_{2} \mathrm{Et}\right)_{2}+ \\
\text { pyroglutamic acid ester }\end{array}$ \\
\hline 11 & 10, R' $=\mathrm{CO}_{2} \mathrm{Et}$ & $\mathrm{NaH}, \mathrm{CH}_{2} \mathrm{Cl}_{2}$ & trace \\
\hline 12 & 10, $\mathrm{R}^{\prime \prime}=\mathrm{CO}_{2} \mathrm{Et}$ & MW & - \\
\hline 13 & $10, \mathrm{R}^{\prime \prime}=\mathrm{CO}_{2} \mathrm{Et}$ & $\mathrm{NaHCO}_{3}, \mathrm{CH}_{2} \mathrm{Cl}_{2}$, reflux & $17 \%$ \\
\hline
\end{tabular}

TLC monitoring of the reaction mixtures indicated that when selenoamide and $\alpha$-bromoester were mixed together, the selenoamide disappeared quickly, suggesting the facile formation of $\alpha$ selenoimine or $\alpha$-selenoiminium salts. TLC analysis of a comparative experiment of $\mathbf{1 0}$ and its sulfur analogue ${ }^{5}$ with diethyl bromomalonate suggested the rapid formation of the suspected $\alpha-$ selenoimine compared to $\alpha$-thioimine. This observation is consistent with the fact, that the nucleophilicity of selenium is greater than sulfur. The TLC observations also suggested that the subsequent change of $\alpha$-selenoimine or $\alpha$-selenoiminium salts into the enamino esters was slow and suffered from the decomposition of these intermediates under reaction conditions. The use of a strong base (entries 9 and 11), however, did not facilitate the selenium contraction. It is known, that the tertiary thioamides produce higher yields of enamino esters with shorter reaction times than secondary thioamides, due to the increased acidity of the $S$-alkyl $\alpha$-proton. ${ }^{1}$ Thus, using the same analogy, tertiary selenoamides should be better than secondary selenoamides. However, in our case (compare entries 5 and 6 with 13) we did not see any improvements with this change. 


\section{Conclusions}

The change of sulfur with selenium, in the two-step mechanism of the Eschenmoser coupling reaction seems to have a positive effect on the first step. However, the second step of the mechanism seems to slow down using selenium. This could possibly be due to the greater size of the selenium atom, which might disfavour the formation of the episelenide intermediate, and hence the production of enamino ester. However, we have shown that, for selected cases, the reaction is possible and enamino esters can be obtained in moderate yields.

\section{Experimental Section}

General Procedures. ${ }^{1} \mathrm{H}$, and ${ }^{13} \mathrm{C}$ NMR spectra were recorded at 500 , and $126 \mathrm{MHz}$ respectively, the solvent used is shown in parenthesis. The chemical shifts are reported in $\delta$ (ppm) values relative to $\mathrm{CHCl}_{3}\left(\delta 7.26 \mathrm{ppm}\right.$ for ${ }^{1} \mathrm{H}$ NMR and $\delta 77.0 \mathrm{ppm}$ for ${ }^{13} \mathrm{C} \mathrm{NMR}$ ). Coupling constants are reported in hertz $(\mathrm{Hz})$. All air and/or moisture sensitive reactions were carried out under argon atmosphere. Solvents (tetrahydrofuran, ether, dichloromethane, dimethylformamide) were dried using a commercial purification system. N-Methyl-2pyrrolidone was dried using Dean-Stark apparatus. All other commercial reagents were obtained from the major chemical supplier and used without any further purification.

1-Piperidino-1-octanone (6b). Octanoyl chloride $(3.50 \mathrm{~mL}, 20.2 \mathrm{mmol})$ was added to a solution of piperidine $(1.00 \mathrm{~mL}, 10.11 \mathrm{mmol})$ in dry $\mathrm{CH}_{2} \mathrm{Cl}_{2}(10 \mathrm{~mL})$ at $0{ }^{\circ} \mathrm{C}$. Potassium carbonate $(1.40 \mathrm{~g}, 10.1 \mathrm{mmol})$ was added and the mixture was stirred for $20 \mathrm{~h}$ at $\mathrm{rt}$. Water was carefully poured in and the mixture was extracted with $\mathrm{CH}_{2} \mathrm{Cl}_{2}$. The $\mathrm{CH}_{2} \mathrm{Cl}_{2}$ layer was dried with $\mathrm{MgSO}_{4}$ and concentrated. Flash chromatography $\left(0 \%, 30 \%\right.$ then $100 \%$ EtOAc in hexanes) afforded $\mathbf{6 b} .{ }^{19}$

\section{General procedure for the synthesis of selenoamides}

Woollins reagent $(93.0 \mathrm{mg}, 0.174 \mathrm{mmol})$ was added to a solution of amide $(0.637 \mathrm{mmol})$ in dry $\mathrm{CH}_{2} \mathrm{Cl}_{2}(6 \mathrm{~mL})$. The reaction was stirred for $24 \mathrm{~h}$ in a sealed tube. The solution was chromatographed to give the corresponding selenoamide.

1-Methylpyrrolidine-2-selenone (8). Using the general procedure, NMP $(121 \mu \mathrm{L}, 1.26 \mathrm{mmol})$ was converted to selenoamide 8. ${ }^{17 \mathrm{~b}}$ Column chromatography $\left(\mathrm{CH}_{2} \mathrm{Cl}_{2}\right)$ afforded the pure compound 8 (49.0 mg, $0.328 \mathrm{mmol}, 26 \%$ yield). ${ }^{1} \mathrm{H}$ NMR $\left(500 \mathrm{MHz}, \mathrm{CDCl}_{3}\right) \delta 3.7$ (t, $J=7.5$ $\mathrm{Hz}, 2 \mathrm{H}), 3.39$ (s, 3H), 3.07 (t, $J=8.0 \mathrm{~Hz}, 2 \mathrm{H}), 2.09$ (dt, $J=7.5,8.0, \mathrm{~Hz}, 2 \mathrm{H})$.

(S)-Ethyl 1-benzyl-5-selenoxopyrrolidine-2-carboxylate (9). By the above general procedure, $\mathrm{N}$-benzylpyroglutamic acid ethyl ester ${ }^{22}(215 \mathrm{mg}, 0.869 \mathrm{mmol})$ was converted to crude selenoamide 9. Column chromatography (40\% EtOAc in hexanes) afforded the semi-pure compound 9 ( $60.0 \mathrm{mg}, 0.192 \mathrm{mmol}, 22 \%$ yield by NMR) along with the recovery of starting material (169 mg, $0.683 \mathrm{mmol}, 78 \%) .{ }^{1} \mathrm{H}$ NMR $\left(500 \mathrm{MHz}, \mathrm{CDCl}_{3}\right) \delta 7.87-7.23(\mathrm{~m}, 1 \mathrm{H}), 7.45-$ 
$7.19(\mathrm{~m}, 4 \mathrm{H}), 5.82(\mathrm{~d}, J=14.5 \mathrm{~Hz}, 1 \mathrm{H}), 4.36(\mathrm{~d}, J=14.5 \mathrm{~Hz}, 1 \mathrm{H}), 4.15(\mathrm{dd}, J=3.0,9.0 \mathrm{~Hz}, 1 \mathrm{H})$, 4.07 (q, $J=7.0 \mathrm{~Hz}, 2 \mathrm{H}), 3.13-3.06(\mathrm{~m}, 1 \mathrm{H}), 3.02-2.95(\mathrm{~m}, 1 \mathrm{H}), 2.24-2.15(\mathrm{~m}, 1 \mathrm{H}), 2.10-2.05(\mathrm{~m}$, $1 \mathrm{H}), 1.18(\mathrm{t}, J=7.0 \mathrm{~Hz}, 3 \mathrm{H}) ;{ }^{13} \mathrm{C} \mathrm{NMR}\left(125 \mathrm{MHz}, \mathrm{CDCl}_{3}\right) \delta 207.5,169.4,134.0,129.1,129.0$, $128.7,67.2,62.3,53.6,48.3,25.8,14.3$.

(S)-Ethyl 5-selenoxopyrrolidine-2-carboxylate (10). By the above general procedure, crude pyroglutamic acid ethyl ester ${ }^{5}(100 \mathrm{mg}, 0.637 \mathrm{mmol})$ was converted to selenoamide 10. Column chromatography (40\% EtOAc in hexanes) afforded the semi-pure compound 10 (38.0 mg, $0.172 \mathrm{mmol}, 27 \%$ yield by $\mathrm{nmr}$ over two steps). ${ }^{1} \mathrm{H} \mathrm{NMR}\left(500 \mathrm{MHz}, \mathrm{CDCl}_{3}\right) \delta 9.20$ (br s $\left.1 \mathrm{H}\right)$, $4.51(\mathrm{dd}, J=6.0,8.5 \mathrm{~Hz}, 1 \mathrm{H}), 4.24$ (q, $J=7.0 \mathrm{~Hz}, 2 \mathrm{H}), 3.00-2.93(\mathrm{~m}, 1 \mathrm{H}), 2.89-2.82(\mathrm{~m}, 1 \mathrm{H})$, 2.57-2.50 (m, 1H), 2.35-2.28 (m, 1H), $1.27(\mathrm{t}, J=7.0 \mathrm{~Hz}, 3 \mathrm{H}) ;{ }^{13} \mathrm{C} \mathrm{NMR}\left(125 \mathrm{MHz}, \mathrm{CDCl}_{3}\right) \delta$ 208.9, 169.4, 65.1, 62.5, 47.4, 27.5, 14.3 .

\section{General procedure for the Eschenmoser coupling}

A solution of selenoamide $(0.082 \mathrm{mmol})$ in dry $\mathrm{CH}_{2} \mathrm{Cl}_{2}(1 \mathrm{~mL})$ was added to a solution of $\alpha$ bromo1,3-dicarbonyl compound $(0.130 \mathrm{mmol})$ in dry $\mathrm{CH}_{2} \mathrm{Cl}_{2}(2 \mathrm{~mL})$. Sodium bicarbonate $(35.0 \mathrm{mg}, 0.300 \mathrm{mmol}$ ) was added after $5 \mathrm{~min}$. and the mixture was allowed to stir/reflux for appropriate time in a sealed tube. Chromatography of the resultant gave the corresponding enaminoester.

Diethyl 2-(1-methylpyrrolidin-2-ylidene)malonate (11). Using the above general procedure, selenoamide 8 (12.2 $\mathrm{mg}, 0.082 \mathrm{mmol})$ was converted to enaminoester 11 after being stirred for $24 \mathrm{~h}$. Column chromatography (30\%, then 100\% EtOAc in hexanes) afforded the pure compound 11 (29.0 mg, $0.029 \mathrm{mmol}, 35 \%$ yield). $\left.{ }^{20}{ }^{1} \mathrm{H} \mathrm{NMR} \mathrm{(500MHz,} \mathrm{CDCl}_{3}\right) \delta 4.17$ (q, J=7.0 Hz, 4H), $3.51(\mathrm{t}, J=7.0 \mathrm{~Hz}, 2 \mathrm{H}), 3.16(\mathrm{t}, J=7.5 \mathrm{~Hz}, 2 \mathrm{H}), 2.85(\mathrm{~s}, 3 \mathrm{H}), 1.94-2.00(\mathrm{~m}, 2 \mathrm{H}), 1.27(\mathrm{t}, J=7.0$ $\mathrm{Hz}, 6 \mathrm{H}) ;{ }^{13} \mathrm{C} \mathrm{NMR}\left(125 \mathrm{MHz}, \mathrm{CDCl}_{3}\right) \delta 168.5$ (2 X C), 166.9, 89.5, 60.1 (2 X C), 57.5, 38.5, $35.8,20.9,14.1$.

Ethyl 2-(1-methylpyrrolidin-2-ylidene)-3-oxo-3-phenylpropanoate (12). By the above general procedure, selenoamide 8 (14.7 $\mathrm{mg}, 0.099 \mathrm{mmol})$ was converted to enaminoester $12^{21}$ after being stirred for $24 \mathrm{~h}$. Column chromatography $\left(\mathrm{CH}_{2} \mathrm{Cl}_{2}\right)$ afforded the pure compound $\mathbf{1 2}$ as a single diastereomer (6.70 mg, $0.026 \mathrm{mmol}, 26 \%$ yield). ${ }^{1} \mathrm{H}$ NMR $\left(500 \mathrm{MHz}, \mathrm{CDCl}_{3}\right) \delta 7.73(\mathrm{~d}, J=8.0$ $\mathrm{Hz}, 2 \mathrm{H}), 7.41(\mathrm{~d}, J=6.5 \mathrm{~Hz}, 1 \mathrm{H}), 7.36(\mathrm{dd}, J=6.5,8.0 \mathrm{~Hz}, 2 \mathrm{H}), 3.83(\mathrm{~d}, J=7.0 \mathrm{~Hz}, 2 \mathrm{H}), 3.65$ (t, $J=7.5 \mathrm{~Hz}, 2 \mathrm{H}), 3.26(\mathrm{t}, J=7.5 \mathrm{~Hz}, 2 \mathrm{H}), 2.75(\mathrm{~s}, 3 \mathrm{H}), 2.09-2.03(\mathrm{~m}, 2 \mathrm{H}), 0.71(\mathrm{t}, J=7.0 \mathrm{~Hz}$, $3 \mathrm{H}) ;{ }^{13} \mathrm{C} \mathrm{NMR}\left(125 \mathrm{MHz}, \mathrm{CDCl}_{3}\right) \delta 194.2,170.7,169.3,142.8,130.9,128.3,128.1,97.0,59.5$, 57.8, 39.1, 35.8, 20.9, 13.7.

Ethyl 5-(ethoxycarbonylmethylselanyl)-3,4-dihydro-2H-pyrrole-2-carboxylate (13). Ethyl bromoacetate $(17.0 \mathrm{mg}, 0.10 \mathrm{mmol})$ was added to a solution of selenoamide $\mathbf{1 0}(0.100 \mathrm{mmol})$ in dry $\mathrm{CH}_{2} \mathrm{Cl}_{2}(1 \mathrm{~mL})$ and the reaction was stirred for $17 \mathrm{~h}$. Sodium ethoxide $(15.0 \mathrm{mg}$, $0.179 \mathrm{mmol}$ ) was added at $0{ }^{\circ} \mathrm{C}$ and the solution was stirred for $2 \mathrm{~h}$ at $\mathrm{rt}$. The mixture was chromatographed to give the $\alpha$-selenoimine 13 in semi-pure form $(7.00 \mathrm{mg}, 0.022 \mathrm{mmol}, 23 \%$ yield by NMR). ${ }^{1} \mathrm{H}$ NMR $\left(500 \mathrm{MHz}, \mathrm{CDCl}_{3}\right) \delta 4.7-4.67(\mathrm{~m}, 1 \mathrm{H}), 4.23-4.17(\mathrm{~m}, 4 \mathrm{H}), 3.92(\mathrm{~d}, J=$ $14.0 \mathrm{~Hz}, 1 \mathrm{H}), 3.85$ (d, $J=14.0 \mathrm{~Hz}, 1 \mathrm{H}), 2.93-2.86(\mathrm{~m}, 1 \mathrm{H}), 2.79-2.73(\mathrm{~m}, 1 \mathrm{H}), 2.34-2.26(\mathrm{~m}$, 
$1 \mathrm{H}), 2.23-2.16(\mathrm{~m}, 1 \mathrm{H}), 1.31-1.26(\mathrm{~m}, 6 \mathrm{H}) ;{ }^{13} \mathrm{C} \mathrm{NMR}\left(125 \mathrm{MHz}, \mathrm{CDCl}_{3}\right) \delta$ quaternary carbons were not observed, 74.6, 61.9, 61.3, 40.8, 27.5, 26.1, 14.4, 14.3.

5-(Diethyoxycarbonylmethylidene)-pyrrolidine-2-carboxylic acid ethyl ester (14). By the above general procedure for Eschenmoser coupling reaction, selenoamide 10 (22.0 $\mathrm{mg}$, $0.100 \mathrm{mmol}$ ) was converted to enaminoester 14 after being refluxed for $48 \mathrm{~h}$. Column chromatography $\left(\mathrm{CH}_{2} \mathrm{Cl}_{2}\right)$ afforded the pure compound $14\left(5.2 \mathrm{mg}, 0.017 \mathrm{mmol}, 17 \%\right.$ yield). ${ }^{1} \mathrm{H}$ NMR $\left.\left(500 \mathrm{MHz}, \mathrm{CDCl}_{3}\right) \delta 9.60(\mathrm{~s}, 1 \mathrm{H}), 4.40(\mathrm{~m}, 1 \mathrm{H})\right), 4.02-4.38(\mathrm{~m}, 6 \mathrm{H}), 3.00-3.20(\mathrm{~m}, 2 \mathrm{H})$, 2.22-2.40 (m, 1H), 2.03-2.20 (m, 1H), 1.20-1.40 (m, 9H).

\section{Acknowledgements}

The authors are grateful to the University of Louisville, Department of Chemistry, and the National Science Foundation (CHE-0513483) for support. SRH is also thankful to Dr. Mark G. Moloney, under whose guidance he first observed the limitations of the Eschenmoser coupling reaction.

\section{References}

1. Shiosaki, K. In Comprehensive Organic Synthesis; Trost, B. M.; Fleming, I., Eds; Pergamon: Oxford, 1991; Vol. 2, p. 865.

2. Munchhof, M. J.; Meyers, A. I. J. Am. Chem. Soc. 1995, 117, 5399.

3. Campbell, J. A.; Rapoport, H. J. Org. Chem. 1996, 61, 6313.

4. Pinchon, M.; Figadere, B. Tetrahedron Asymmetry 1996, 7, 927.

5. Hussaini, S. R.; Moloney, M. G. Org. Biomol. Chem. 2006, 4, 2600.

6. Michael, J. P.; Koning, C. B.; Malefetse, T. J.; Yillah, I. Org. Biomol. Chem. 2004, 2, 3510.

7. Gaunt, M. J.; Johansson, C. C. C.; McNally, A.; Vo, N. T. Drug Discovery Today 2007, 12, 8.

8. Mitsumori, S.; Zhang, H.; Cheong, P. H.-Y.; Houk, K. N.; Tanaka, F.; Carlos F. Barbas, I. J. Am. Chem. Soc. 2006, 128, 1040.

9. Marchand, P.; Fargeau-Bellassoued, M.-C.; Bellec, C.; Lhommet, G. Synthesis 1994, 1118.

10. Gugelchuk, M. M.; Hart, D. J.; Tsai, Y.-M. J. Org. Chem. 1981, 46, 3671.

11. Petersen, J. S.; Fels, G.; Rapoport, H. J. Am. Chem. Soc. 1984, 106, 4539.

12. Bachi, M. D.; Breiman, R.; Meshulam, H. J. Org. Chem. 1983, 48, 1439.

13. Roth, M.; Dubs, P.; Gotschi, E.; Eschenmoser, A. Helv. Chim. Acta 1971, 54, 710.

14. Hussaini, S. R. D.Phil. Thesis, University of Oxford, Oxford, 2004.

15. Russowsky, D.; Neto, B. A. d. S. Tetrahedron Lett. 2004, 45, 1437.

16. Ende, D. V.; Krief, A. Tetrahedron Lett. 1975, 31, 2709. 
17. (a) Gray, I. P.; Bhattacharyya, P.; Slawin, A. M. Z.; Woollins, J. D. Chem. Eur. J. 2005, 11, 6221. (b) Bethke, J.; Karaghiosoff, K.; Wessjohann, L. A. Tetrahedron Lett. 2003, 44, 6911.

18. Ireland, R. E.; Jr.; Brown, F. R. J. Org. Chem. 1980, 45, 1868.

19. Jensen, A. E.; Knochel, P. J. Org. Chem. 2002, 67, 79.

20. Singh, H.; Batra, M. S.; Singh, P. Indian J. Chem., Sect B 1984, $23 B, 1176$.

21. Dannhardt, G.; Bauer, A. Pharmazie 1996, 51, 805.

22. Deskus, J.; Fan, D.; Smith, M. B. Synth. Comm. 1998, 28, 1649. 